\title{
Integrated reporting and corporate social responsibility in the context of social economy \\ (Mutual associations in the health and welfare sector)
}

\section{Maria Brízida Faria de Sousa Tomé, Deolinda Aparício Meira \& Ana Maria Alves Bandeira}

\section{ABSTRACT}

This study aims to evaluate whether integrated reporting can be considered the appropriate tool for disclosure of the socially responsible behaviour of social economy entities (SEEs), as they currently face an increased demand for transparency from a number of stakeholders. The initial analysis of the concept and principles of corporate social responsibility (CSR), through a triple bottom line concept, and of the social economy and the legal regime governing mutual associations is followed by an empirical study of Portuguese mutual associations in the health and welfare sector. A proposal is also made for an integrated reporting system which is suitable for showing the organization's socially responsible behaviour and pursuit of the general interest and is concluded to have overcome the difficulties of disclosing their economic, social, and environmental aspects. Furthermore, it is proposed that SEES should obligatorily adopt integrated reporting in order to transmit dynamic, up-to-date information of relevance to stakeholders.

KEYWORDS: Corporate social responsibility, general interest, integrated reporting, mutual association, social economy, sustainable development, transparency.

ECONLIT DESCRIPTORS: M140, M410, M490, P190, Q560.

Reference: FARIA DE SOUSA, M.B., MEIRA, D.A. \& BANDEIRA, A.M. (2015): "Integrated reporting and corporate social responsibility in the context of social economy", CIRIEC-España, Revista de Economía Pública, Social y Cooperativa, 85, 109-142.

Contact: Maria Brízida Faria de Sousa Tomé, Deolinda Aparício Meira, Ana Maria Alves Bandeira, Instituto Politécnico do Porto/ISCAP. E-mails: brizida.tome@gmail.com, meira@iscap.ipp.pt, bandeira@iscap.ipp.pt. 


\section{El informe integrado y la responsabilidad social corporativa en el contexto de la economía social (Una asociación mutua del sector de la salud y bienestar)}

RESUMEN: Este estudio tiene como objetivo evaluar si el informe integrado puede ser considerado el instrumento adecuado para la divulgación del comportamiento socialmente responsable de las entidades de economía social (EES), ya que se enfrentan actualmente a una demanda de transparencia creciente, por las partes interesadas/ por los interesados. A partir de un análisis del concepto y de los principios de la responsabilidad social corporativa (RSC), con el término de triple bottom line, de la economía social y del marco legal de las mutuas, se procede con un estudio empírico sobre la asociación mutua portuguesa (sector de Salud y Bienestar). Complementariamente, se presenta una propuesta de un sistema de informe integrado adecuado para mostrar el comportamiento social responsable de la organización y la búsqueda del interés general, concluyendo que las dificultades de divulgación sobre aspectos económicos, sociales y ambientales se superan adecuadamente. Se propone además la adopción obligatoria, para el futuro, del informe integrado en las EES, para transmitir una información dinámica, actualizada y relevante para los stakeholders.

PALABRAS CLAVE: Responsabilidad social corporativa, interés general, informe integrado, asociación mutua, economía social, desarrollo sostenible, transparencia.

\section{Le rapport intégré et la responsabilité sociale des entreprises dans le contexte de l'économie sociale (Association mutuelle se trouvant dans le secteur de la santé et du bien-être)}

RÉSUMÉ : Cette étude a pour objectif d'évaluer si le rapport intégré peut être considéré comme un outil approprié pour la vulgarisation du comportement socialement responsable des entités de l'économie sociale (EES), lesquelles doivent actuellement faire face à une demande croissante de transparence, imposée par les stakeholders. À partir de l'analyse du concept et des principes de responsabilité sociale des entreprises (RSE), en termes de triple performance, de l'économie sociale et du cadre juridique des mutuelles, nous procédons à une étude empirique d'une association mutuelle portugaise (secteur de la santé et du bien-être). De plus, nous présentons une proposition d'un système de rapport intégré apte à souligner le comportement social responsable de l'organisation et la poursuite de l'intérêt général. Nous sommes amenés à conclure que les difficultés de communication sur les aspects économiques, sociaux et environnementaux sont surmontées de façon appropriée. Nous proposons, en outre, l'adoption obligatoire, à l'avenir, du rapport intégré par les EES, afin de transmettre une information dynamique, actualisée et pertinente pour les stakeholders.

MOTS CLÉ : Responsabilité sociale des entreprises, intérêt général, rapport intégré, association mutuelle, économie sociale, développement durable, transparence. 


\section{1.- Introduction}

First establishing that Corporate Social Responsibility (CSR) integrates the genetic code of the social economic entities (SEE), as their goals are situated both on business and on social domains, not only simultaneously but through a perspective of complementarity (Meira, 2011, pp 293-305, 2012a, pp 127-144. 2012b, pp 291-308), this study intends to reflect the particularities that the integrated reporting to be applied by these entities should have, in order to provide a clear evidence of their socially responsible behavior.

Following this context, the juridical and accounting regimes that regulate the SEE are based on a social paradigm in accordance with the fundamental principles of the CSR. The influence of these fundamental principles is strongly visible on several Portuguese diplomas, namely the Law $n^{0} 30 / 2013$, dated May 8, referred to as the social economy law (LBES) - (Meira, 2013, pp 21-52); the DecreeLaw (DL) $n^{\circ} 72 / 1990$, on March 3, which found the Code for the Mutual Associations (CAM); and the $\mathrm{DL} \mathrm{n}^{\circ}$ 36-A/2011, dated March 9, establish the accounting harmonized regime for the entities of the non-profit sector (ESNL). Therefore, these diplomas will provide the framework for our study.

In this study we will start by tracing the concept of CRS, mainly based on documents issued by the EU (European Union), so that we can afterwards concentrate on the basic principles of social economy, integrating part of the LBES, which must be pursued by the Mutual Associations.

We will, furthermore, focus on a Mutual Association situated on the Health and Welfare sector, in order to state whether this entity issues an integrated reporting or if its disclosure goes beyond the financial reporting, enabling proper evidence of its socially responsible behavior.

For this purpose, we use the concept of integrated reporting, built over a set of indicators on which the CSR principles are settled. 


\section{2.- CSR concept and principles}

The CSR concept has been defined by the Commission of the European Communities (2001), on the Green Book ${ }^{1}$ to promote an European social framework for the companies' social responsibility, related to the companies who decide to follow, voluntarily, all measures leading to the contribution of a more fair society and to a cleaner environment.

The CSR goals, according to the social policy of the EU, follow a strategy favorable to sustainable development, embracing the European values and therefore focusing on the respect of the human rights, environment protection, pollution reduction, rational use of natural resources, social and environmental innovation, labor protection, continuous formation of employees and employability, inclusion of the disadvantaged groups on the labor market, and public health improvement, among others (European Commission, 2011, 2013).

This CSR concept is not bounded, being in a continuous process of development over the last decades. We, therefore, decided to proceed with a literature analyses on its evolution and on the importance it reveals on the business ground. There are quite a large number of theoretical approaches that defend the CSR insertion on the business strategies, which leads us to list some of the most important theories as well as their consequent effects over the company's concept.

For a better look at the connection between each theory that could be followed and the related changes produced on the business strategy and the company's concept, we'll present a table integrating those aspects and relations.

\section{Table 1. CSR conceptual evolution versus company's perception and goals}

\begin{tabular}{|l|l|l|l|}
\hline Source & CSR and company's profile & Goals & $\begin{array}{l}\text { CSR and com- } \\
\text { pany's relation }\end{array}$ \\
\hline Friedman (1970) & $\begin{array}{l}\text { Shareholder's Theory: CRS is limited to the maximiza- } \\
\text { tion of the shareholders' profit. Organizational manage- } \\
\text { ment only takes into account the law and ethical } \\
\text { principles commonly accepted. }\end{array}$ & Shareholders' profit. & Almost none. \\
\hline
\end{tabular}




\begin{tabular}{|c|c|c|c|}
\hline $\begin{array}{l}\text { Meyer and } \\
\text { Rowan (1977); } \\
\text { Dimaggio and } \\
\text { Powell (1983) }\end{array}$ & $\begin{array}{l}\text { Institutional Theory: considers the importance of the } \\
\text { company's approach to several stakeholders, through } \\
\text { mimetic, isomorphic, proactive, or coercive strategies. }\end{array}$ & $\begin{array}{l}\text { A company's legiti- } \\
\text { macy near his stake- } \\
\text { holders; increase of } \\
\text { visibility and notoriety. }\end{array}$ & $\begin{array}{l}\text { Partial and punctual } \\
\text { for the stakeholders. }\end{array}$ \\
\hline Freeman (1984) & $\begin{array}{l}\text { Stakeholder's Theory: extending the business objectives, } \\
\text { integrating concerns centered on transparent, ethical, } \\
\text { and responsible attitudes and behaviors towards all the } \\
\text { stakeholders, far beyond the shareholder's profit. }\end{array}$ & $\begin{array}{l}\text { The shareholders' pro- } \\
\text { fit increased through } \\
\text { social and environ- } \\
\text { mental concerns. } \\
\end{array}$ & $\begin{array}{l}\text { Total and permanent } \\
\text { relation with all sta- } \\
\text { keholders. }\end{array}$ \\
\hline $\begin{array}{l}\text { Melo Neto and } \\
\text { Froes (1999) }\end{array}$ & $\begin{array}{l}\text { These authors relate the exercise and importance of CSR } \\
\text { to the multiplicity of the strategic objectives followed by } \\
\text { the companies, who as a result of their missions, values, } \\
\text { and organizational plans, are taken to build up very varia- } \\
\text { ble and disperse CSR actions. Authors still rely to this } \\
\text { optional multiplicity to the acting sphere where the com- } \\
\text { pany develops its actions, which could be only of internal, } \\
\text { or external range or even both: } \\
\text { i. If the goal is to improve the results of the organizatio- } \\
\text { nal culture, the company will endeavor to create a } \\
\text { CSR policy voted to the internal dimension; } \\
\text { ii. If the purpose is to achieve a better performance of } \\
\text { their intangible assets, such as reputation or brand's } \\
\text { value, the CSR policy to follow will be rather focused } \\
\text { on the external environment. }\end{array}$ & $\begin{array}{l}\text { - sustainability and } \\
\text { business performance } \\
\text { improvement; } \\
\text { - promotion and moti- } \\
\text { vation of their human } \\
\text { capital; } \\
\text { - search of an increa- } \\
\text { sed "socially correct" } \\
\text { status, in appreciation } \\
\text { of their offer; } \\
\text { - application of their } \\
\text { ecological sense; } \\
\text { - social integration; } \\
\text { - relational and/or ins- } \\
\text { titutional marketing; } \\
\text { - personal or collec- } \\
\text { tive citizenship; } \\
\text { - philanthropy. }\end{array}$ & $\begin{array}{l}\text { Variable as per the } \\
\text { goals pursued as } \\
\text { well as the different } \\
\text { action levels. }\end{array}$ \\
\hline Heal (2005) & $\begin{array}{l}\text { The CSR concept by Heal (2005) is approached under an } \\
\text { economistic perspective. } \\
\text { CSR programs are seen as a way to settle conflicts, in } \\
\text { order to efficiently contribute to the positive impacts in } \\
\text { terms of image, legitimacy, or even increasing the com- } \\
\text { petitive advantage and the profit itself. The author men- } \\
\text { tions examples such as: } \\
\text { - Minimizing business venture and capital cost; } \\
\text { - Reinforcing brand equity; } \\
\text { - Promoting human relationships and workers' productivity; } \\
\text { - Reducing waste and pollution; } \\
\text { - Improving relationships with regulators; } \\
\text { Controversial measurement of results. }\end{array}$ & $\begin{array}{l}\text { Prediction and control } \\
\text { of conflicts to a minor } \\
\text { level, between com- } \\
\text { panies and the } \\
\text { society, held through } \\
\text { the alignment of pri- } \\
\text { vate and social costs } \\
\text { or through a balanced } \\
\text { partition of both. }\end{array}$ & $\begin{array}{l}\text { Coordination based } \\
\text { on a social role } \\
\text { focus. }\end{array}$ \\
\hline Velasco (2005) & $\begin{array}{l}\text { Reflects on the latest serious scandals witnessed on the } \\
\text { capitalistic economy, basing on these facts his perspec- } \\
\text { tive regarding the malfunction of the economy without } \\
\text { higher and moral shared values. This author encourages } \\
\text { a new social function of the company. }\end{array}$ & $\begin{array}{l}\text { Limited excess of inte- } \\
\text { rest, conditioning it } \\
\text { not merely to the profit } \\
\text { or to the individual } \\
\text { level, but rather brin- } \\
\text { ging social legitimacy } \\
\text { to the companies. }\end{array}$ & $\begin{array}{l}\text { Questions of good } \\
\text { governance, econo- } \\
\text { mic rationality, con- } \\
\text { duct codes, or legal } \\
\text { rules on manage- } \\
\text { ment procedures will } \\
\text { emerge. }\end{array}$ \\
\hline
\end{tabular}




\begin{tabular}{|c|c|c|c|}
\hline Torre (2005) & $\begin{array}{l}\text { Supports a company's "new" social function. } \\
\text { In this regard, CSR has to be envisaged not as a marke- } \\
\text { ting action, or as an image promotional measure, with } \\
\text { short-term impacts, rather than the essence of the busi- } \\
\text { ness itself, generating an identity and proper organizatio- } \\
\text { nal culture. } \\
\text { The company becomes socially responsible in every acti- } \\
\text { vity area, where the decision-making procedures are } \\
\text { included. Companies that have not undertaken such a } \\
\text { behavior will have to change their tactics; otherwise, they } \\
\text { will certainly suffer important losses of competitive } \\
\text { advantages in the medium or large term. }\end{array}$ & $\begin{array}{l}\text { - wealth and employ- } \\
\text { ment creation within the } \\
\text { community where the } \\
\text { company develops his } \\
\text { activity; } \\
\text { - promotion of the respect } \\
\text { for the human rights, } \\
\text { - environmental and } \\
\text { labor protection; } \\
\text { - non-discrimination; } \\
\text { - technological deve- } \\
\text { lopment; } \\
\text { - consumers protection. }\end{array}$ & $\begin{array}{l}\text { Interrelation between } \\
\text { social, economic, } \\
\text { and environment } \\
\text { dimensions. }\end{array}$ \\
\hline $\begin{array}{l}\text { Jamali and } \\
\text { Mirshak (2006) }\end{array}$ & $\begin{array}{l}\text { These authors underscore the great variability of posi- } \\
\text { tions that a company may take toward CSR. } \\
\text { They sustain the conceptual model of CSR proposed by } \\
\text { Carroll (1979 e 1991), divided into } 4 \text { motivational levels: } \\
\text { the economic, the legal, the ethical, and the discretio- } \\
\text { nary, ranked in a pyramid. } \\
\text { Admitting the lack of agreement upon the CSR concept, } \\
\text { quoting other authors (Clement, J-2005; Murray-2005), } \\
\text { who consider that the adhesion to CSR is commonly a } \\
\text { hypocritical dissimulation from the company with the } \\
\text { exclusive pretension to maximize results, taking advan- } \\
\text { tage from the social participation. }\end{array}$ & $\begin{array}{l}\text { Also variable in the } \\
\text { function of the multipli- } \\
\text { city of options pursued. }\end{array}$ & $\begin{array}{l}\text { Depending on com- } \\
\text { pany's attitude: } \\
\text { reactive, defensive, } \\
\text { accommodative, or } \\
\text { proactive. }\end{array}$ \\
\hline $\begin{array}{l}\text { Castelo Branco } \\
\text { (2006) }\end{array}$ & $\begin{array}{l}\text { This author also asserts that motivations to conduct the } \\
\text { adoption of CSR should follow a ranking, dividing those } \\
\text { motivations under several perspectives: the economistic, } \\
\text { the conformist, the positive approach, and the proactive } \\
\text { approach. }\end{array}$ & $\begin{array}{l}\text { Also variables in func- } \\
\text { tion of the multiplicity of } \\
\text { options are pursued. }\end{array}$ & $\begin{array}{l}\text { Depending on com- } \\
\text { pany's attitude: } \\
\text { reactive, defensive, } \\
\text { accommodative, or } \\
\text { proactive. }\end{array}$ \\
\hline $\begin{array}{l}\text { Nicolau and } \\
\text { Simaens (2008) }\end{array}$ & $\begin{array}{l}\text { They realize that the several and extended procedures of } \\
\text { CSR to be undertaken can bring advantages and disad- } \\
\text { vantages to their players, which have to be taken into } \\
\text { account when deciding on the actions to be pursued (eg., } \\
\text { cultural differences, level of autonomy, centralization or } \\
\text { specialization, costs for coordination of the programs or } \\
\text { procedures controlling). }\end{array}$ & $\begin{array}{l}\text { Most common variables: } \\
\text { - social projects (internal); } \\
\text { - donations (philanthropy); } \\
\text { - sponsorships (part- } \\
\text { nerships); } \\
\text { - Alliances (common } \\
\text { projects). }\end{array}$ & $\begin{array}{l}\text { Different degrees of } \\
\text { involvement from the } \\
\text { parts, depending on } \\
\text { the proper demands } \\
\text { of the adopted } \\
\text { model. }\end{array}$ \\
\hline
\end{tabular}




\begin{tabular}{|c|c|c|c|}
\hline $\begin{array}{l}\text { Kiran and } \\
\text { Sharma (2011) }\end{array}$ & $\begin{array}{l}\text { These authors defend that the companies would have to } \\
\text { adopt an attitude of social commitment and ethic busi- } \\
\text { ness behavior that, beyond the pursuit of profit, would } \\
\text { position them as active participants in their community } \\
\text { development; they should generate value and promote } \\
\text { welfare and common good, in a win-win relation. } \\
\text { Simultaneously, CSR will grant these companies the legi- } \\
\text { timacy and competitive advantage. }\end{array}$ & $\begin{array}{l}\text { CSR's leverage capa- } \\
\text { city can be seen: } \\
\text { At the internal level: } \\
\text { as higher motivation for } \\
\text { the company's wor- } \\
\text { kers, an increase in } \\
\text { productivity as well as } \\
\text { improvement of the } \\
\text { organizational culture } \\
\text { in general; } \\
\text { At the external level: } \\
\text { In an increase in the } \\
\text { prestige, notoriety, and } \\
\text { reputation of the com- } \\
\text { pany, reinforcing their } \\
\text { intangible assets value, } \\
\text { while making them less } \\
\text { susceptible to imitation. }\end{array}$ & $\begin{array}{l}\text { Interrelation between } \\
\text { the social, economic, } \\
\text { and environment } \\
\text { dimensions. }\end{array}$ \\
\hline
\end{tabular}

SOURCE: Prepared by the authors.

As per the content of the above table, the CSR's concept can be seen as the most open reality, as far as it can have an enormous variability of objectives, within which several procedures for its prosecution are also possible.

We consider that this theoretical analysis contributes to the evidence of the CSR's controversial definition. This lack, in light of the multiplicity of goals traced as well as of the variety of arrangements pursued, can be considered as the cause, or even the effect, of its inaccurate determination. These can also be seen as the motives to constrain the CSR's evolution, its disclosure, and general public recognition.

The above-mentioned theories also lead us to a conclusion, which seems to be consensual, that CSR's practice goes beyond the regulatory and coercive conventions: the companies who assume it, voluntarily, are driven into a high and demanding level of social development, environmental protection, and defense of fundamental right: they simultaneously promote business strategies for the benefit of all stakeholders, enlarging the quality of their offer, as long as they are contributing to their sustainable development.

All of this reflection upon CSR applies to the social economy entities (SEEs), as they simultaneously follow social and business objectives, having furthermore incorporated into their DNA the fundamental principles of CSR itself. 
Following Nicolau and Simaens' thoughts (2008), the SEEs have been enlarging and developing their interest groups, including actually, besides their beneficiaries (associates), their workers, suppliers, and public organisms. Furthermore, they are reinforcing their business strategies, organizational culture, and environmental behavior, thus improving their products and services offered, their relationship with the community, and taking better management steps for fundraising and resource allocation, therefore increasing their sustainability.

\section{3.- Mutual Associations and CSR}

Mutual associations integrate the social economy sector [(al. b) do art.4 LBES)].

In Portugal, the Code for the Mutual Associations (CAM), on art.1, defines the mutual associations as the Private Institutions of Social Solidarity (PISS), with an unlimited number of associates, undefined capital and duration, which mutual aid purposes are practiced on behalf of their members and families, essentially through their contributions. As they are considered as PISS, they are complementarily regulated by the PISS Statute (DL nr. 172-A/2014, dated November 14, revoking the older DL nr. 119/83).

May we emphasize that mutual associations, which has been registered in legal terms, automatically acquire the quality of legal persons of public interest (art.16 CAM)2.

The main purpose of the mutual associations is the mutual aid, practiced in the interest of their associates and families (CAM - art.1). There are still quite a large number of special purposes that these institutions may follow, such as the granting of social security and health benefits (nr.1 do art.2), cumulatively extensible to other means of social protection and quality of life promotion, ever since they look forward to the moral, intellectual, cultural, and physical development of their beneficiaries (nr.2 do art.2). Furthermore, there are some specific purposes that can be considered as part of the function of the mutual associations (CAM- art.3), enlarging their activity on the social security scope, (i.e. several disability benefits, age, or survival pensions and other complementary benefits to some special situations that may arise, such as disease, maternity, unemployment, working accidents, or professional diseases). Still in this regard of specific functions that mutual associations can assume, article

2.- The Public Interest Statute has been approved by DL 460/77, dated November 07, changed and republished by DL 391/2007, from the 13th December, formulating a base of attribution of this status both to associations and foundations, to private legal persons who pursue purposes of general interest, as well as collective persons of public utility. 
4 of the same code (CAM) considers the activities on the health range, such as preventive, curative or rehabilitation medical care or medication assistance. Therefore, all of these activities are recognized and likely to be developed by mutual associations.

A very important factor about the SEEs is that, as part of the social economy sector, the economic and social activities they undertake are submitted to the prosecution of the general interest of their members, users, and beneficiaries, although these activities might also have to be considered as socially relevant, which is specifically required by law (LBES nr. 2, art.2).

This connection made by the legislator, bounding the concept of social economy to the prosecution of the general interest, links intrinsically the SEE to the adoption of socially responsible behaviors.

One of the basic guiding principles of the social economy is therefore remarked, taking as a pillar the person's primacy and the social objectives over the capital [(al. a) do art.5 - LBES)].

Based on all the aspects above on the mutual associations, there is no doubt that they follow their objectives, simultaneously, in the social and economic domains, on a complementarity basis (Meira, 2011, pp 293-305, 2012, pp 127-144, 2012b, pp 291-308).

We are standing before entities constituted under the auspices of a non-profit purpose, which does not suggest a complete absence of results (as far as their performance and continuity requires their sustainability). Nevertheless, primarily, they should intend to provide the satisfaction of their members' needs and, in return, those of the community where they are inserted.

Having in mind the legal framework of the mutual associations, we shall defend that there is a legal duty attached to the corporate board members of these associations, by which, despite the fact that they would have to be centered on the satisfaction of the needs of their associates, they will have to work carefully in order to achieve the sustainable development of their community, following the criteria approved by the members on a general assembly.

We can add to this point that the proper social object of the mutual associations relies on the satisfaction of the needs of all their members (namely the access to health care and complementary regimes of social security, amongst others), rendering those needs that other corporate operators present on the market in-adequately met, which by other means demonstrates the social function of the mutual associations.

This social function is shown up on the economical regime of those entities, mainly because their property does not rely on a capital basis, but in endowments or capital reserves, with the purpose of guaranteeing the maintenance of the related charges, without any dividends affordable as far as those funds are meant to be indivisible and non-distributable. 
Through article 52, nr.1, from CAM, the surplus distribution is expressly prohibited, which is corroborated by articles 52 and 53, on a combined logic of social activity with the technical and financial balance of the activities undertaken (sustainability).

This normative regulation matches the rule set by LBES (art.5- al. g), limiting the surplus allocation to the prosecution of the SEEs' purposes, in accordance to the general interest.

It becomes clear that the members of the board of those mutual associations cannot separate their governance from the social function pursued by these entities.

That is to say that those members of the board will be obliged to integrate with the association's activity the CSR's fundamental values, announced by the World Council for Business Sustainable Development (WCBSD-2013) and by the Business Council for Sustainable Development (BCSD-2013), through the adoption of the best practices in terms of solidarity, equality and non-discrimination, social cohesion, justice and equity, transparency, and particular and social shared responsibility, whose are also considered as the guideline principles defined by LBES (art.5 - al. e).

\section{4.- CSR and the accounting system of the mutual associations. Special reference to the integrated reporting.}

From an accounting point of view, mutual associations are ruled by the Accounting Normalization System for the entities of the non-profit sector (ESNL), named as SNC-ESNL 3 .

This regime is applied, as mandatory, only to those entities achieving a business volume (sales or other income values) over $150.000 €$, held for two consecutive years. If these conditions are not realized, the normative will not be effective. These SEEs who will not be submitted to this normative, or that will not comply with it voluntarily, are obliged to perform the disclosure through the cash accounting regime.

However, this accounting regime does not expressly establish any obligation as far as the use of the integrated reporting is concerned or mentions the sustainability report.

Then, we can claim that the legislator disregarded all initiatives driven throughout the last decades, encouraging the adoption of the sustainability reports.

3.- Approved by DL nr.36-A/2011, dated March 09, implemented as mandatory at the 1st January 2012, regulating entities performing social activities. SNC-ESNL abolishes former sectorial plans, till then defined for the PISS by DL 78/89 and for the mutual associations by DL 295/95. 
Between the main initiatives on this regard we focus on those promoted by the Global Reporting Initiative (GRI, 2013), in cooperation with the United Nations Global Compact, Organization for Economic Co-operation and Development (OECD, 2010), International Finance Corporation (IFC), and ISO International Organization for Standardization (ISO)-(ISO 26000 e SA8000), presenting an international structure for the use of the sustainable reports as well as for the integrated reporting (International Integrated Reporting Council- IIRC, 2013a, 2013b), as a way of promoting the sustainability of the organizations, once contributing to the best practices of management (planning, management and control), and therefore for their sustainable development.

The vision defined by IIRC foresees integrated thinking, conductive to the efficient and productive allocation of capital, and the integrated reporting will enable the disclosure of the creation of value, in a most clear and dynamic way, providing a simultaneous and non-static statement, while it function as a driving force capable of granting to the organizations the financial stability and sustainability needed for the achievement of their goals (Bakker, 2013).

As per the IIRC (2013a), "integrated reporting has been created for any organization that wants to embrace integrated thinking and progress their corporate reporting. Businesses have reported breakthroughs in understanding value creation, greater collaboration within their teams, more informed decision making and positive impacts on stakeholder relations". The IIRC definition for the integrated reporting is the way companies "communicate a clear, concise, integrated story that explains how all their resources are creating value. Integrated reporting help businesses to think holistically about their strategy and plans, make informed decisions, and manage key risks to build investor and stakeholder confidence and improve future performance. It is shaped by a diverse coalition including business leaders and investors to drive a global evolution in corporate reporting" (IIRC, 2013a, 2013b).

In this way, both IIRC (2013b) and GRI (2013) advise the use of this kind of reports, presenting some principles to follow, so that disclosure will achieve a higher level of accountability and sustainability. The international structure of the integrated reporting is seen as a guideline that is appropriate to the orientation and definition of the structural framework and could enhance the innovation of corporate report while at the same time ameliorating the efficiency of the disclosure process itself.

Meanwhile, these structural principles are flexible enough as to allow them to fit into the different realities of each organization, guaranteeing however, the required comparability. Nevertheless, there is no imposition whatsoever on any specific indicators for the evaluation of performance, measurement, or disclosure.

The indicators advised by GRI (2013) and IIRC (2013b) aim to approach the internal and external environments of each entity, the reason they outline basic principles that will comprehend the company's strategy and organizational profile, governance, ethics, and integrity among the most relevant aspects. 
As previously mentioned, these data would have to be followed generally, with great independence of the indicators chosen. However, the advice for disclosure goes beyond those elements, as there are other categories that would have to be included related to economic, social, and environmental reporting, following a triple bottom-line concept. Those categories can also be divided into some subcategories, if adequate.

The information to be reported, and the way to do it, will depend on the strategy and position of each entity. In this regard, we mention the GRI - G4 Guidelines (General Standard Disclosures and Aspects per sector), in which we can find advice on the most relevant aspects to the report, to be taken as a standard, per category:

\section{Table 2. Disclosure and Aspects per sector}

\begin{tabular}{|c|c|c|c|c|c|c|}
\hline \multirow{2}{*}{$\begin{array}{l}\text { Categories } \\
\text { Sub- } \\
\text { categories }\end{array}$} & \multirow[t]{2}{*}{ Economic } & \multirow[t]{2}{*}{ Environmental } & \multicolumn{4}{|c|}{ Social } \\
\hline & & & $\begin{array}{l}\text { Politics } \\
\text { /Labour } \\
\end{array}$ & $\begin{array}{l}\text { Human } \\
\text { Rights }\end{array}$ & Society & $\begin{array}{l}\text { Product } \\
\text { Responsibility }\end{array}$ \\
\hline \multirow[t]{10}{*}{ Aspects } & $\begin{array}{l}\text { Economic } \\
\text { performance }\end{array}$ & Materials & Employment & Investment & $\begin{array}{l}\text { Local } \\
\text { Community }\end{array}$ & $\begin{array}{l}\text { Customer's } \\
\text { Health and Safety }\end{array}$ \\
\hline & Market share & Energy & $\begin{array}{l}\text { Occupational } \\
\text { health/ Safety }\end{array}$ & $\begin{array}{l}\text { Non- } \\
\text { discrimination }\end{array}$ & Anti-corruption & $\begin{array}{l}\text { Labelling } \\
\text { standards }\end{array}$ \\
\hline & $\begin{array}{l}\text { Indirect economic } \\
\text { impacts }\end{array}$ & Water & $\begin{array}{l}\text { Education / } \\
\text { Formation }\end{array}$ & $\begin{array}{l}\text { Freedom } \\
\text { association }\end{array}$ & $\begin{array}{l}\text { Public } \\
\text { Policies }\end{array}$ & $\begin{array}{l}\text { Marketing } \\
\text { communication }\end{array}$ \\
\hline & $\begin{array}{l}\text { Procurement } \\
\text { practices }\end{array}$ & Biodiversity & $\begin{array}{l}\text { Diversity / } \\
\text { Equality }\end{array}$ & Child labour & $\begin{array}{l}\text { Good compe- } \\
\text { tition rules }\end{array}$ & $\begin{array}{l}\text { Customer's } \\
\text { Privacy }\end{array}$ \\
\hline & $\begin{array}{l}\text { Resources } \\
\text { allocation }\end{array}$ & Emissions & $\begin{array}{l}\text { Remuneration } \\
\text { Policy }\end{array}$ & $\begin{array}{l}\text { Security } \\
\text { practices }\end{array}$ & Conformity & Conformity \\
\hline & $\begin{array}{l}\text { Socially } \\
\text { responsible } \\
\text { investment }\end{array}$ & $\begin{array}{l}\text { Products and } \\
\text { Services }\end{array}$ & $\begin{array}{l}\text { Supplier } \\
\text { selection by } \\
\text { labour politic }\end{array}$ & $\begin{array}{l}\text { Supplier's } \\
\text { Human } \\
\text { Rights }\end{array}$ & $\begin{array}{l}\text { Supplier's } \\
\text { Assessment- } \\
\text { social impacts }\end{array}$ & $\begin{array}{l}\text { Stakeholders' } \\
\text { relation }\end{array}$ \\
\hline & $\begin{array}{l}\text { Ethical } \\
\text { fundraising }\end{array}$ & $\begin{array}{l}\text { Customer } \\
\text { Service }\end{array}$ & $\begin{array}{l}\text { Complaint } \\
\text { norms }\end{array}$ & $\begin{array}{l}\text { Complaint } \\
\text { norms }\end{array}$ & $\begin{array}{l}\text { Complaint } \\
\text { norms }\end{array}$ & $\begin{array}{l}\text { Complaints and } \\
\text { actions }\end{array}$ \\
\hline & & & & & & Gender Equality \\
\hline & & & & & & $\begin{array}{l}\text { Awareness and } \\
\text { defense of public } \\
\text { interests }\end{array}$ \\
\hline & & & & & & Coordination \\
\hline
\end{tabular}

SOURCE: Prepared by the authors, as per GRI (2013). 
Following this same characterization, Castelo-Branco (2006) proposes the creation of a set of indicators adequate to all categories, classified as per the range of actions pursued, that would enable their planning, control, and disclosure. The proposed classification would be divided regarding the actions undertaken, extended from human resources to environmental aspects, products, and consumer information or even to community involvement, in addition to the economic perspective.

At this stage, we must underline the difficulty of the definition of such indicators, mainly due to the great variety of actions pursued and the possible modalities followed, yet increased by the rather difficult measurability of those categories or subcategories.

In this context, in the opinion of Socias \& Horrach (2013), there is still to be considered a different range of appreciation of the indicators traced, as some of these parameters can be measured by their immediate market value, others being susceptible to the currency appreciation or even of rather difficult evaluation. Therefore, the gradient of appreciation per indicator would always be considered as possible, susceptible, or difficult. Furthermore, these indicators would have to be evaluated through their impact on an economic perspective (surplus application, added value, or future wealth creation) or through the social impacts they could produce (sales/services, training costs, labour creation/stability/productivity, beneficiary satisfaction and external cooperation, as well as the improvement in their quality of life).

Some SEEs are already reporting quite large information in this regard, but there are still other indicators that have a manifested lack of disclosure, which are highly recommended by GRI (2013), by WBCSD - World Business Council for Sustainable Development (2013) and by IIRC (2013a; 2013b) to be included on the sustainable reports of such entities.

As far as the sustainable reports are concerned, we would like to stress that they are built in a time lag in relation to the financial reports, causing some loss of dynamism and, simultaneously, preventing complete information on the entity's performance on several domains. The integrated reporting comes up in response to such weaknesses shown by the sustainable report, showing an integrated vision, where financial and the sustainable reports are merged and avoid the time lag on the disclosed information.

We therefore defend that the integrated reporting shall be mandatory for the mutual associations and for all other SEEs, as this is of the highest importance not only to their members or beneficiaries, but also to all third parties involved with the entity and to the public authorities. As far as public entities are concerned, the integrated report will certainly provide a better and more appro- 
priate mean to control the SEEs' actions. In fact, the principle of protection of the cooperative and social sector is consecrated under article 80th of the Portuguese Constitution, as well as under articles 10 and 11 of the LBES. By this principle, the promotion of the SEE becomes mandatory to the public authorities, whereby the SEEs are entitled to a positive discrimination towards the rest of the private entities operating on the market. This positive discrimination is translated in terms of tax benefits granting more favorable conditions on access to credit, amongst other material conditions related to their development (Meira, 2013, pp 21-52). The main fundament for this special treatment remains on the fact that these entities pursue general interest objectives, which, by itself, implies accounting tools attesting that same pursuit.

In addition, the mutual associations in their quality of PISS are submitted to inspections by the Ministry of Trusteeship, mainly based on the need to prove the general interest pursuit; that is to say, attesting their socially responsible behavior. In this way, the adoption of disclosure practices that would grant such information becomes reinforced.

In this sense, the integrated reporting emerges as the more adequate accounting instrument to provide the necessary operational transparency of these entities.

In this context, we are presenting a proposal for indicators, which we consider to be adequately fitted to the preparation of an integrated reporting (Tables 3, 4, 5, 6, and 7).

Throughout these tables we will list a set of categories under which the SEEs' socially responsible behavior can be evaluated and presented in five groups: Human Resources (Table 3); Products/Services (Table 4); Sustainability (fundraising and funds allocations) (Table 5); Community relationship (Table 6); and Environmental behavior (Table 7). We aim to establish the interrelation between the disclosure pursued by category with the mutualist principles, namely those of Solidarity, Equality, Social Cohesion, and Networking, mainly with the purpose of checking the evidence (or not) of the mutual association's socially responsible behavior. For this purpose, we sorted out the proposed indicators belonging to a certain category, following their relation within each of the announced principles. 


\section{Table 3. SEEs' social responsible behavior indicators. Category: Human Resources}

\begin{tabular}{|l|l|l|l|}
\hline \multicolumn{4}{|c|}{ Principles } \\
\hline Solidarity & Equality & Social cohesion & Networking \\
\hline Jobs creation & Gender equality (male / female) & Employment of minorities & $\begin{array}{l}\text { Project developments, sharing } \\
\text { and optimizing resources } \\
\text { in conjunction with SEEs. }\end{array}$ \\
\cline { 1 - 3 } Number of employees & & & \\
\hline Remuneration policy & Assigned remunerations & & \\
\hline Education / Training & & & \\
\hline
\end{tabular}

SOURCE: Prepared by the authors.

As can be seen in Table 3, the proposed indicators for the human resources category are then related to each of the mutual principles, and those will be the propositions we will follow on the content analysis to be made on our case study.

In Table 4, we will present the indicators considered adequate for the Products and Services category, on which we will subsequently rely for further content analysis, following the same logic as previously stated:

\section{Table 4. SEEs' social responsible behavior indicators Category: Products and services}

\begin{tabular}{|c|c|c|c|}
\hline \multicolumn{4}{|c|}{ Principles } \\
\hline Solidarity & Equality & Social cohesion & Networking \\
\hline $\begin{array}{l}\text { Auscultation of Community } \\
\text { needs / Close relationship }\end{array}$ & $\begin{array}{l}\text { Equal treatment (marital situations/ } \\
\text { family/gender/race - ex: age } \\
\text { requirement for pensions; } \\
\text { women's protection on Maternity). }\end{array}$ & Offer extension & $\begin{array}{l}\text { Project developments, } \\
\text { sharing and optimizing } \\
\text { resources in conjunction } \\
\text { with SEEs. }\end{array}$ \\
\hline \multicolumn{4}{|l|}{ New projects / services: } \\
\hline $\begin{array}{l}\text { - Social integration projects } \\
\text { (exclusion/poverty/family's } \\
\text { malfunction) }\end{array}$ & Non-discrimination & Social inclusion & \\
\hline $\begin{array}{l}\text { - Social protection programs/ } \\
\text { new or traditional risk groups }\end{array}$ & Non-discrimination & & \\
\hline $\begin{array}{l}\text { - Promotion of quality of life } \\
\text { programs (Ex. social security } \\
\text { complementary regimes) }\end{array}$ & Non-discrimination & $\begin{array}{l}\text { Alternatives to the } \\
\text { public sector } \\
\text { regimes }\end{array}$ & \\
\hline
\end{tabular}

SOURCE: Prepared by the authors. 
Following the same approach, Table 5 presents the proposed indicators for later analysis, this time in the sustainability category.

\section{Table 5. SEEs' social responsible behavior indicators Category: Sustainability}

\begin{tabular}{|l|l|l|l|}
\hline \multicolumn{3}{|c|}{ Principles } \\
\hline Solidarity & Equality & Social cohesion & Networking \\
\hline Fundraising: & & State & \\
- Donations & & Market & \\
- Aids & & Other Entities & \\
- Quota & & & \\
\hline Resources allocation: & & State & \\
\hline Reserves & & Other Entities & \\
New social businesses development & & Other Public support & \\
\hline
\end{tabular}

SOURCE: Prepared by the authors

As far as the category related to the community relationship, a set of indicators is defined as adequate to further analysis, stated on Table 6 :

\section{Table 6. SEEs' social responsible behavior indicators Category: Community Relationship}

\begin{tabular}{|l|l|l|l|}
\hline \multicolumn{4}{|c|}{ Principles } \\
\hline Solidarity & Equality & Social cohesion & Networking \\
\hline $\begin{array}{l}\text { Events (conferences, sports } \\
\text { events, cultural events, ASO) }\end{array}$ & & & Network Synergies \\
\hline $\begin{array}{l}\text { Users' defense (quality / } \\
\text { service or product security }\end{array}$ & & & \\
\hline No relocation & & & \\
\hline
\end{tabular}

SOURCE: Prepared by the authors.

Finally, Table 7 lists the indicators to follow on the evaluation of the socially responsible behavior as far as environmental issues are concerned: 


\section{Table 7. SEES' social responsible behavior indicators Category: Environment}

\begin{tabular}{|l|l|l|l|}
\hline \multicolumn{3}{|c|}{ Principles } \\
\hline Solidarity & Equality & Social cohesion & Networking \\
\hline $\begin{array}{l}\text { Information on } \\
\text { environmental impacts } \\
\text { concerning: }\end{array}$ & & $\begin{array}{l}\text { Project developments, and } \\
\text { sharing and optimizing resources } \\
\text { in conjunction with SEEs. }\end{array}$ \\
\hline - Products & & & \\
- Procedures & & \\
- Efficiency & & \\
- Energy expenditure & & & \\
\hline $\begin{array}{l}\text { Information on practices } \\
\text { meant for environmental } \\
\text { end ecological awareness. }\end{array}$ & & & \\
\hline
\end{tabular}

SOURCE: Prepared by the authors.

Based on these proposed indicators, we will sustain our case study built on a Mutual Association belonging to the Health and Welfare sector, presented below.

\section{CASE STUDY}

The Mutual Associations are considered to be of significant social-economic interest amongst the other SEE of the Portuguese Social Economy sector (cooperatives, mercies, Private Institutions of Social Solidarity-PISS, and others), reflected on the Satellite Accounts (CASES, 2013 and INE, 2013), referred to 2010, as per Table 8. 


\section{Table 8. Portuguese Social Economy - GAV / Remuneration (2010)}

\begin{tabular}{|c|c|c|c|c|c|c|c|c|c|c|c|c|c|}
\hline \multirow[t]{2}{*}{ SEE } & \multicolumn{2}{|c|}{ Units } & \multicolumn{2}{|c|}{ ETC $\left(^{*}\right) /$ Remun. } & $\%$ & \multicolumn{2}{|c|}{ GAV $\left(^{* \star}\right)$} & $\%$ & \multicolumn{2}{|c|}{ Remuneration } & $\%$ & GAV/empl. & Remun./Empl \\
\hline & $(\mathrm{nr})$ & $\%$ & $\left(n^{0}\right)$ & $\%$ & SE & $10^{6} €$ & $\%$ & SE & $10^{6} €$ & $\%$ & SE & \multicolumn{2}{|c|}{$10^{6} €$ per ETC } \\
\hline Cooperatives & 2260 & 4,1 & 31783 & 14,0 & 0,8 & 749,2 & 17,6 & 0,5 & 657,3 & 16,6 & 0,8 & 23,6 & 20,7 \\
\hline Mutuals & 119 & 0,2 & 4537 & 2,0 & 0,1 & 329,9 & 7,7 & 0,2 & 176,2 & 4,5 & 0,2 & 72,7 & 38,8 \\
\hline Mercies & 381 & 0,7 & 32493 & 14,3 & 0,8 & 518,3 & 12,2 & 0,3 & 426,9 & 10,8 & 0,5 & 16,0 & 13,1 \\
\hline Foundations & 537 & 1,0 & 10765 & 4,7 & 0,3 & 361,1 & 8,5 & 0,2 & 215,1 & 5,4 & 0,2 & 33,5 & 20,0 \\
\hline Associations & & & & & & & & & & & & & \\
\hline and other SEE & 52086 & 94,0 & 147357 & 64,9 & 3,6 & 2304,1 & 54,1 & 1,5 & 2479,9 & 62,7 & 2,9 & 15,6 & 16,8 \\
\hline Total SEE & 55383 & 100,0 & 226935 & 100,0 & 5,5 & 4262,6 & 100,0 & 2,8 & 3955,4 & 100,0 & 4,6 & 18,8 & 17,4 \\
\hline Total Economy & & & 4138163 & & & 151426 & & & 86814 & & & 36,6 & 21,0 \\
\hline
\end{tabular}

Note: (*) ETC - Work units equivalent to full time staff; ( $\left(^{*}\right)$ GAV represents the Gross Added Value.

SOURCE: Prepared by the authors, adapted from CASES (2013) and INE (2013).

In order to highlight the relevance of the Mutual Associations, it should be stressed that: despite in terms of units they only represent $0,2 \%$ from the total, they show an important contribution to the GAV $(7,7 \%)$ and to Remuneration (4,5\%), which, compared to the other social entities, is remarkable. This is also reinforced by the ratios GAV/Employment and Remuneration/Employment $(72,7$ and 38,8, respectively), expressing the positive preponderance of these indicators over all other SEE and also over the total economy (36,6 and 21,0, respectively).

In turn, as per Satellite Accounts (2013, reported to 2010), the Mutual Associations, Cooperatives and Foundations evidence a financing capacity of 54,1 millions of Euros, as long as the other SEE present a net borrowing need by the 570,7 Millions of Euros.

The above mentioned factors, together with the fact that the Mutual Associations have been less studied, determined our choice to go forward with this study, focusing on the Mutual Associations group.

In order to determine a subgroup for our specific study, we proceeded with an analysis that could corroborate the leverage capacity of these SEE, through a research of their resources and expenses.

The analysis showed that, even if the largest number of SEE are concentrated on the Social action group, the importance of the Health and Welfare group is highlighted, as their fundraising is mainly obtained through the production factor $(83,4 \%)$, with a minor dependence from transfers and subsidies $(8 \%)$. 
Concerning expenditure, the main values are located on the intermediate consumptions $(54,9 \%$, related to the production factors), and also on the remunerations (38,3\%), reaffirming the previous ratio of Remuneration/Employment $(38,8)$, highly superior to the national average $(21,0)$.

We also took in mind the geographical preponderance of the mutual associations, finding that there are $36 \%$ of the total mutual associations at the district of Porto and $27 \%$ at district of Lisbon, suggesting that our investigation should focus on a mutual association situated at the North of Portugal.

Nevertheless, we started with a general approach to the mutual associations registered at the Social Security (80 contacts held over the 97 entities registered - see annex I). These contacts were mainly held by e-mail, phone and some meetings, trying to collect the financial reports, plans of activities and budgets. We also tried to achieve the information needed by their websites, through UMP - Union of the Portuguese Mutual Associations (2013), through SABI - Sistema de Análise de Balanços Ibéricos (Iberian balance sheet analysis system).

From those contacts we only received 10 answers (10,3\% from the total), some declining the possibility to provide the required information, others providing only the financial report (1), which was not enough to the case study we intended to follow.

Hence, our choice fell on the Mutual Association Liga das Associações de Socorro Mútuo de Vila Nova de Gaia (LASMVNG), considered to mutually comply with requirements of the model we intend to analyze.

Making a short presentation of LASMVNG, this was established in 1905.

LASMVNG's head office is located in Rua Serafim Rodrigues da Rocha, 39, 4400-306 Vila Nova de Gaia. Contacts: Phone: 223771015; Fax: 223771016; web-page: http://www.ligagaia.pt; e-mail: geral@ ligagaia.pt.

Turnover 2013: 5,377.883,39€

Number of employees: 35

This is an aggregation of three associations from the same locality, namely "Associação Oliveirense de Socorros Mútuos" (from 1893), "A Vilanovense - Associação Mutualista" (since1882, with 50.000 members) and "Montepio Vilanovense de Socorro Mútuo Costa Goodolphim" (from 1921), first established with the purpose of rendering several complementary services such as funeral grants.

This institution works nationwide, having the social object defined as to render social security complementary services (complements of unemployment benefits, supplements of retirement allowances, and retirement savings) as well as medical assistance and medication services, extended to all 3 associations. 
These health and welfare services are specially granted through the Farmácia da Liga (Liga's Pharmacy), the Clínica da Liga (Liga's Clinic) with 25 clinical specialties, nursing and clinical analysis, and the Clínica de Estética (Aesthetics Clinic) offering complementary medicines, rehabilitation therapies, beauty treatments and pharmacist monitoring, thus meeting the community needs. It is actually participating on some networking programs, namely Rede Mut and Mutuália, through which it optimizes synergies and achieves a larger offer of additional services of domiciliary health and insurances, respectively, therefore contributing to the reinforcement of benefits to its associates.

Taking into account the proposal of indicators presented previously (Tables 3 to 7) grouped into five categories (Human Resources, Products and Services, Sustainability - Fundraising and Resource Allocation, Community Relationship and Environment Behavior) we intend mainly to evaluate the LASMVNG's disclosure performance.

At this stage, further to the previous proposed relation, we present a re-organization also attending to the 3 levels wherever CSR is commonly evaluated, under the triple bottom-line concept (economic, social, and environment forums), detailing for each item a measurement or evaluation method for the indicator and also classifying its variable measurability $((\mathrm{M}+, \mathrm{M}-$ or $\mathrm{M} 0)$ corresponding to more or less measurable or even difficult to measure items.

The mutual principles, already connected to the indicators, will be represented by their initials, i.e.: $\mathrm{S}=$ Solidarity, $\mathrm{E}=\mathrm{E}$ quality, $\mathrm{SC}=\mathrm{Social}$ cohesion and $\mathrm{N}=$ Networking. The analysis of contents made on this case study, are then showed in Tables 9 to 13, under a classification of $y=y e s, n=n o$, and $p=p a r-$ tial, which will be used for the final evaluation.

\section{Table 9. Proposed indicators for disclosure of CSR by SEE and respective classification on the Case study Category: Human Resources. Level: Social}

\begin{tabular}{|c|c|c|c|c|c|c|}
\hline \multirow[t]{2}{*}{ Principles } & \multicolumn{2}{|r|}{ Indicators } & \multicolumn{3}{|c|}{ Measurability } & \multirow{2}{*}{$\begin{array}{l}\text { Case study } \\
\text { LASMVNG }\end{array}$} \\
\hline & & & $M+$ & M- & MO & \\
\hline S & Jobs creation & $\begin{array}{l}\text { Ratio: number of workers } \\
\text { Year } 0 \text { and Year - } 1\end{array}$ & - & - & M0 & $\mathrm{n}$ \\
\hline S & $\begin{array}{l}\text { Number of } \\
\text { employees }\end{array}$ & $\begin{array}{l}\text { Number of workers } \\
\text { Year } 0 \text { and Year }-1\end{array}$ & - & - & M0 & $\mathrm{p}$ \\
\hline S & $\begin{array}{l}\text { Remuneration } \\
\text { policy }\end{array}$ & $\begin{array}{l}\text { Average wage/information } \\
\text {-plans and proper actions }\end{array}$ & $\mathrm{M}_{+}$ & - & Mo & p \\
\hline S & Social Benefits & Total volume of benefits granted & $\mathrm{M}_{+}$ & - & - & $n$ \\
\hline$E$ & $\begin{array}{l}\text { Assigned } \\
\text { remunerations }\end{array}$ & $\begin{array}{l}\text { Payroll to Management } \\
\text { and Corporate bodies }\end{array}$ & $\mathrm{M}+$ & - & - & $\mathrm{n}$ \\
\hline$E$ & Gender equality & $\begin{array}{l}\text { Policy towards inclusion and } \\
\text { no labor discrimination. }\end{array}$ & - & - & MO & $\mathrm{n}$ \\
\hline
\end{tabular}


INTEGRATED REPORTING AND CORPORATE SOCIAL RESPONSIBILITY IN THE CONTEXT OF

SOCIAL ECONOMY

\begin{tabular}{|c|c|c|c|c|c|c|}
\hline S & $\begin{array}{l}\text { Worker's needs } \\
\text { attendance }\end{array}$ & $\begin{array}{l}\text { Information on means of } \\
\text { communication used (media,...) }\end{array}$ & - & - & Mo & $\mathrm{n}$ \\
\hline S & Promotional policy & $\begin{array}{l}\text { \%promotions (based on value } \\
\text { or number of promotions) }\end{array}$ & $\mathrm{M+}$ & - & Mo & $n$ \\
\hline S & $\begin{array}{l}\text { Health and } \\
\text { Security }\end{array}$ & $\begin{array}{l}\text { Ratio: H\&S expenditures / } \\
\text { workers attending }\end{array}$ & $\mathrm{M}_{+}$ & - & - & $n$ \\
\hline SC & $\begin{array}{l}\text { Employee's } \\
\text { satisfaction }\end{array}$ & Absenteeism rates / productivity & $\mathrm{M+}$ & - & - & $\mathrm{n}$ \\
\hline SC & $\begin{array}{l}\text { Employment of } \\
\text { Minorities (exclusion) }\end{array}$ & $\begin{array}{l}\% \text { workers (minorities) / } \\
\text { total } n \text { jobs creation }\end{array}$ & - & - & Mo & $\mathrm{n}$ \\
\hline S & $\begin{array}{l}\text { Training / } \\
\text { Education }\end{array}$ & $\begin{array}{l}\% \text { workers attending to specific } \\
\text { formation }\end{array}$ & - & - & Mo & $\mathrm{n}$ \\
\hline $\mathrm{N}$ & $\begin{array}{l}\text { Common Projects - } \\
\text { resources optimization } \\
\text { with other SEEs. }\end{array}$ & Stating alliances or partnerships & - & - & Mo & $\mathrm{n}$ \\
\hline
\end{tabular}

SOURCES: GRI-GR4, (2013); Moneva, Ortas and Acero (2013); Socias and Horrach (2013) - composed by the authors.

\section{Table 10. Proposed indicators for disclosure of CSR by SEE and respective classification on the Case study. Category: Products and Services. Level: Social}

\begin{tabular}{|c|c|c|c|c|c|c|}
\hline \multirow{3}{*}{$\begin{array}{c}\text { Principles } \\
\text { S }\end{array}$} & \multicolumn{2}{|c|}{ Indicators } & \multicolumn{3}{|c|}{ Measurability } & \multirow{2}{*}{$\begin{array}{l}\text { Case study } \\
\text { LASMVNG }\end{array}$} \\
\hline & & & M+ & M- & Mo & \\
\hline & $\begin{array}{l}\text { Auscultation of } \\
\text { community's needs } \\
\text { / close relationship }\end{array}$ & $\begin{array}{l}\text { Suiting / internal actions } \\
\text { evaluation and control }\end{array}$ & $M+$ & - & - & $y$ \\
\hline \multirow[t]{2}{*}{ S/SC } & Offer extension & New products / services & - & - & Mo & $y$ \\
\hline & \multicolumn{2}{|c|}{ New Projects and Services: } & & & & \\
\hline S/SC & $\begin{array}{l}\text { - Social Integration } \\
\text { (exclusion/poverty) }\end{array}$ & $\begin{array}{l}\text { Qualification and quantification } \\
\text { of products / services }\end{array}$ & $\mathrm{M}+$ & - & - & $\mathrm{y}$ \\
\hline $\mathrm{S} / \mathrm{SC}$ & $\begin{array}{l}\text { - Social protection / } \\
\text { risk groups }\end{array}$ & $\begin{array}{l}\text { Qualification and quantification } \\
\text { of products / social services }\end{array}$ & $M+$ & - & - & $\mathrm{n}$ \\
\hline S/SC & $\begin{array}{l}\text { - Programs for } \\
\text { promote quality of life }\end{array}$ & $\begin{array}{l}\text { Alternative to public sector } \\
\text { regimes }\end{array}$ & $\mathrm{M}+$ & - & - & $\mathrm{y}$ \\
\hline $\mathrm{E}$ & Non- discrimination & Disclosure & - & - & M0 & $n$ \\
\hline S & Quality policy & $\begin{array}{l}\text { Evaluation of user's satisfaction / } \\
\text { suitable organizational actions }\end{array}$ & $\mathrm{M}+$ & - & - & $y$ \\
\hline $\mathrm{N}$ & $\begin{array}{l}\text { Common Projects - } \\
\text { resources optimization }\end{array}$ & $\begin{array}{l}\text { To disclose, } \\
\text { qualify and quantify }\end{array}$ & $\mathrm{M}+$ & - & - & $y$ \\
\hline
\end{tabular}

SOURCES: as provided in Table 9 - composed by the authors.

CIRIEC-España, Revista de Economía Pública, Social y Cooperativa 


\section{Table 11. Proposed indicators for disclosure of CSR by SEE and respective classification on the Case study. Category: Sustainability. Level Economic}

\begin{tabular}{|c|c|c|c|c|c|c|}
\hline \multirow[t]{2}{*}{ Principles } & \multirow{2}{*}{\multicolumn{2}{|c|}{ Indicators }} & \multicolumn{3}{|c|}{ Measurability } & \multirow{2}{*}{$\begin{array}{l}\text { Case study } \\
\text { LASMVNG }\end{array}$} \\
\hline & & & $M+$ & M- & MO & \\
\hline $\mathrm{S} / \mathrm{SC}$ & Fundraising & $\begin{array}{l}\text { Ratio: real and foreseen } \\
\text { resources (efficiency) }\end{array}$ & $\mathrm{M}_{+}$ & - & - & $\mathrm{n}$ \\
\hline $\mathrm{S} / \mathrm{SC}$ & $\begin{array}{l}\text { Donations (State / } \\
\text { market/private sector) }\end{array}$ & Resources sources proportion & $\mathrm{M}_{+}$ & - & - & $\mathrm{n}$ \\
\hline $\mathrm{S} / \mathrm{SC}$ & $\begin{array}{l}\text { Aids (State /market/ } \\
\text { private sector) }\end{array}$ & $\begin{array}{l}\text { Ratio: Public and private } \\
\text { resources }\end{array}$ & $\mathrm{M}_{+}$ & - & - & $n$ \\
\hline S/SC & Quota & Evolution & $\mathrm{M}_{+}$ & - & - & $\mathrm{y}$ \\
\hline $\mathrm{S} / \mathrm{SC}$ & $\begin{array}{l}\text { Resources from } \\
\text { comercial activity }\end{array}$ & Products/services sales evolution & $\mathrm{M}+$ & - & - & y \\
\hline $\mathrm{S} / \mathrm{SC}$ & Resources allocation & $\begin{array}{l}\text { Ratio: total and foreseen } \\
\text { costs (efficiency) }\end{array}$ & $\mathrm{M}+$ & - & - & $\mathrm{n}$ \\
\hline$S$ & Reserves & $\begin{array}{l}\text { Reinvestment volume } \\
\text { - proportion of generated benefits }\end{array}$ & $\mathrm{M}+$ & - & - & $p$ \\
\hline $\mathrm{S} / \mathrm{SC}$ & $\begin{array}{l}\text { New social businesses } \\
\text { development }\end{array}$ & $\begin{array}{l}\text { Ratio: Social Investment / } \\
\text { Total Investment }\end{array}$ & $\mathrm{M}+$ & - & - & $p$ \\
\hline
\end{tabular}

SOURCES: as provided in Table 9 - composed by the authors.

\section{Table 12. Proposed indicators for disclosure of CSR by SEE and respective classification on the Case study. Category: Community Relationship. Level: Social}

\begin{tabular}{|c|c|c|c|c|c|c|}
\hline \multirow[t]{2}{*}{ Principles } & \multicolumn{2}{|c|}{ Indicators } & \multicolumn{3}{|c|}{ Measurability } & \multirow{2}{*}{$\begin{array}{l}\text { Case study } \\
\text { LASMVNG }\end{array}$} \\
\hline & & & $M_{+}$ & M- & MO & \\
\hline$S$ & $\begin{array}{l}\text { Events (conferences, } \\
\text { sports events, cultural } \\
\text { events, ASO) }\end{array}$ & $\begin{array}{l}\text { Workshops, training activities, } \\
\text { conferences for the community }\end{array}$ & $M_{+}$ & - & - & y \\
\hline$S$ & $\begin{array}{l}\text { User's defense } \\
\text { (quality/products/ } \\
\text { services safety) }\end{array}$ & $\begin{array}{l}\text { Implementation of } \\
\text { quality system } \\
\text { or CSR programs }\end{array}$ & $M+$ & - & - & y \\
\hline $\mathrm{S} / \mathrm{SC}$ & No relocation & $\begin{array}{l}\text { Reinforcement / maintenance } \\
\text { of close relationship }\end{array}$ & - & - & M0 & $y$ \\
\hline SC & $\begin{array}{l}\text { Social action } \\
\text { participation }\end{array}$ & $\begin{array}{l}\text { Impacts on organizational policy, } \\
\text { implementation, control }\end{array}$ & - & M- & - & $\mathrm{n}$ \\
\hline
\end{tabular}




\begin{tabular}{|c|l|l|lc|c|}
\hline SC & $\begin{array}{l}\text { Relationship with } \\
\text { competitors }\end{array}$ & Good conduct rules & - & $\mathrm{n}$ \\
\hline SC & $\begin{array}{l}\text { Local suppliers' } \\
\text { purchases }\end{array}$ & $\begin{array}{l}\text { Local development } \\
\text { contribution }\end{array}$ & - & $\mathrm{M} 0$ \\
\hline $\mathrm{N}$ & $\begin{array}{l}\text { Synergies } \\
/ \text { SEE networks }\end{array}$ & To disclose, qualify and quantify & $\mathrm{M}+\quad-$ & - & $\mathrm{y}$ \\
\hline
\end{tabular}

SOURCES: as provided in Table 9 - composed by the authors.

\section{Table 13. Proposed indicators for disclosure of CSR by SEE and respective classification on the Case Study. Category and Level: Environment}

\begin{tabular}{|c|c|c|c|c|c|c|}
\hline \multirow[t]{2}{*}{ Principles } & \multirow{2}{*}{\multicolumn{2}{|c|}{ Indicators }} & \multicolumn{3}{|c|}{ Measurability } & \multirow{2}{*}{$\begin{array}{l}\text { Case study } \\
\text { LASMVNG }\end{array}$} \\
\hline & & & \multirow[t]{2}{*}{ M+ } & \multirow[t]{2}{*}{ M- } & \multirow[t]{2}{*}{ Mo } & \\
\hline & Disclosure on environ & imental impacts due to: & & & & \\
\hline$S$ & - Products & $\begin{array}{l}\text { Specific disclosure on projects } \\
\text { with environmental impact }\end{array}$ & - & - & Mo & $p$ \\
\hline$S$ & - Procedures & & - & - & - & $\mathrm{p}$ \\
\hline$S$ & - Efficiency & $\begin{array}{l}\text { Consumption's control measures } \\
\text { implementation }\end{array}$ & - & M- & - & $\mathrm{n}$ \\
\hline$S$ & $\begin{array}{l}\text { - Energy } \\
\text { expenditure }\end{array}$ & Consumption & - & $\mathrm{M}-$ & - & $n$ \\
\hline $\mathrm{S} / \mathrm{SC}$ & Suppliers selection & $\begin{array}{l}\text { Make evidence of environmental } \\
\text { criteria on suppliers' selection } \\
\text { method. }\end{array}$ & - & - & Mo & $\mathrm{n}$ \\
\hline S/SC & $\begin{array}{l}\text { Information on } \\
\text { practices meant for } \\
\text { environmental and } \\
\text { ecological awareness }\end{array}$ & $\begin{array}{l}\text { Adhesion to environmental policies } \\
\text { (Ex. SA8000; ISO26000; } \\
\text { ISO14000; ISO9001) }\end{array}$ & $M_{+}$ & - & Mo & $\mathrm{y}$ \\
\hline $\mathrm{N}$ & $\begin{array}{l}\text { Common Projects - } \\
\text { resources optimization } \\
\text { with other SEEs. }\end{array}$ & Environmental investments & $M_{+}$ & - & - & $n$ \\
\hline
\end{tabular}

SOURCES: As referred to in Table 9 - composed by the authors. 
This association (LASMVNG) does not use the integrated reporting, or any other kind of sustainability report, which is a common situation amongst the Portuguese mutual associations. Really, we did not find any entity, even between those of bigger dimensions, such as those working on the financial area who may have issued any sustainable report, contrarily to the tender followed in this way, on many other countries, like Spain, as stated by Moneva, Ortas, \& Acero (2013).

For our analysis we took the latest LASMVNG's financial reports $(2011,2012,2013)$, which have been prepared on the basis of the SNC-ESNL accounting system, since 2011, and also inspected the plans of action and yearly budgets referring to 2012, 2013, and 2014.

As a result, we found that this institution discloses quite an important set of information, further than the required financial data. As a matter of fact, having not yet adopted a sustainable report (or an integrated one), they disclose important information on their management and organizational profile, strategic objectives and policies. From this, we also could infer a fundamental worry from this entity on the mutualism development and its principles, both internal and externally.

The results achieved over this association's performance are now reflected on the following tables $(14,15,16,17$, and 18), each of them classified into the five initially chosen categories. May we emphasize that our goal is to evaluate the level of disclosure of this entity, trying to measure its impact over the perception about the socially responsible behavior of this SEE.

\section{Table 14. Solidarity indicator results}

\begin{tabular}{|c|c|c|c|c|c|c|c|c|}
\hline \multirow{2}{*}{$\begin{array}{l}\text { Dategory } \\
\end{array}$} & \multicolumn{8}{|c|}{ Solidarity (17 indicators) } \\
\hline & \multicolumn{2}{|c|}{ yes } & \multicolumn{2}{|c|}{ no } & \multicolumn{2}{|c|}{ partial } & \multicolumn{2}{|c|}{ total } \\
\hline Human Resources & & & 6 & $75 \%$ & 2 & $25 \%$ & 8 & $47 \%$ \\
\hline Products and Services & 2 & $100 \%$ & & & & & 2 & $12 \%$ \\
\hline Sustainability & & & & & 1 & $100 \%$ & 1 & $6 \%$ \\
\hline Community Relationship & 2 & $100 \%$ & & & & & 2 & $12 \%$ \\
\hline Environment & & & 4 & $100 \%$ & & & 4 & $24 \%$ \\
\hline TOTAL & 4 & $23,5 \%$ & 10 & $58,8 \%$ & 3 & $17,6 \%$ & 17 & $100 \%$ \\
\hline
\end{tabular}

SOURCE: Prepared by the authors.

As shown on Table 14, the negative punctuations (no) achieve 58,8\%. Nevertheless, the categories of Products/Services and Community Relationship point to $100 \%$ of positive remarks (yes) individually, despite their meaning rates at only of $24 \%$ on the total proportion of the 17 indicators ( $12 \%$ per each category). 
Table 15. Equality indicator results

\begin{tabular}{|c|c|c|c|c|c|c|}
\hline Category & & & quality & cators) & & \\
\hline Disclosure & yes & & & partial & & \\
\hline Human Resources & & 2 & $100 \%$ & & 2 & $67 \%$ \\
\hline Products and Services & & 1 & $100 \%$ & & 1 & $33 \%$ \\
\hline Sustainability & & & & & & \\
\hline Community Relationship & & & & & & \\
\hline Environment & & & & & & \\
\hline TOTAL & & 3 & $100 \%$ & & 3 & $100 \%$ \\
\hline
\end{tabular}

SOURCE: Prepared by the authors.

The results taken from Table 15 demonstrate that all answers of the equality indicators were no, with a relative importance of $67 \%$ on the human resources and $33 \%$ on the products/services categories. It's visible that no indicators have been determined as far as the rest of the categories are concerned. This is most evident that this kind of analysis also can be very helpful as a management tool, so that the less consequential matters would be highlighted for future concern.

\section{Table 16. Social cohesion indicator results}

\begin{tabular}{|c|c|c|c|c|c|c|}
\hline \multirow{2}{*}{$\begin{array}{l}\text { Category } \\
\end{array}$} & \multicolumn{6}{|c|}{ Social cohesion (5 indicators) } \\
\hline & \multirow[t]{2}{*}{ yes } & \multicolumn{2}{|c|}{ no } & \multirow[t]{2}{*}{ partial } & \multicolumn{2}{|c|}{ total } \\
\hline Human Resources & & 2 & $100 \%$ & & 2 & $40 \%$ \\
\hline \multicolumn{7}{|l|}{ Products and Services } \\
\hline \multicolumn{7}{|l|}{ Sustainability } \\
\hline Community Relationship & & 3 & $100 \%$ & & 3 & $60 \%$ \\
\hline \multicolumn{7}{|l|}{ Environment } \\
\hline TOTAL & & 5 & $100 \%$ & & 5 & $100 \%$ \\
\hline
\end{tabular}

SOURCE: Prepared by the authors.

Also, the 5 proposed indicators for the evaluation of Social cohesion, as per Table 16, are all negative (no), with distributed percentages per Human Resources and Community Relationship at $40 \%$ and $60 \%$, respectively. 
Table 17. Solidarity and Social cohesion indicator results

\begin{tabular}{|c|c|c|c|c|c|c|c|c|}
\hline Category & & & & Social & & indic & & \\
\hline Disclosure & & les & & & & & & \\
\hline Human Resources & & & & & & & 0 & \\
\hline Products and Services & 3 & $75 \%$ & 1 & $25 \%$ & & & 4 & $29 \%$ \\
\hline Sustainability & 2 & $29 \%$ & 4 & $57 \%$ & 1 & $14 \%$ & 7 & $50 \%$ \\
\hline Community Relationship & 1 & $100 \%$ & & & & & 1 & $7 \%$ \\
\hline Environment & 1 & $50 \%$ & 1 & $50 \%$ & & & 2 & $14 \%$ \\
\hline TOTAL & 7 & $50 \%$ & 6 & $43 \%$ & 1 & $7 \%$ & 14 & $100 \%$ \\
\hline
\end{tabular}

SOURCE: Prepared by the authors.

The above table demonstrates a predominance of the positive evaluations (yes), varying between $75 \%$ on the Products/Services, $100 \%$ on the Community Relationship, and $50 \%$ on the Environment categories, despite their relative weights that only correspond to $29 \%, 7 \%$ and $14 \%$, with $57 \%$ of negative answers got on the sustainability class, which substantially reduces their expression.

Finally, Table 18 presents the analysis of the Networking indicators.

\section{Table 18. Networking indicator results}

\begin{tabular}{|c|c|c|c|c|c|c|c|}
\hline \multirow{2}{*}{$\begin{array}{l}\text { Category } \\
\text { Disclosure }\end{array}$} & \multicolumn{7}{|c|}{ Networking (4 indicators) } \\
\hline & \multicolumn{2}{|c|}{ yes } & \multicolumn{2}{|c|}{ no } & \multirow[t]{2}{*}{ partial } & \multicolumn{2}{|c|}{ total } \\
\hline Human Resources & & & 1 & $100 \%$ & & 1 & $25 \%$ \\
\hline Products and Services & 1 & $100 \%$ & & & & 1 & $25 \%$ \\
\hline \multicolumn{8}{|l|}{ Sustainability } \\
\hline Community Relationship & 1 & $100 \%$ & & & & 1 & $25 \%$ \\
\hline Environment & & & 1 & $100 \%$ & & 1 & $25 \%$ \\
\hline TOTAL & 2 & $50 \%$ & 2 & $50 \%$ & & 4 & $100 \%$ \\
\hline
\end{tabular}

SOURCE: Prepared by the authors.

Through the results on the 4 networking indicators, we can see that there are $50 \%$ negative answers and $50 \%$ positive ones. Meanwhile, as far as Products/Services and Community Relationship present individually $100 \%$ of positive performance (yes), the categories of Human Resources and Environment take a completely different expression, which leads to the $50 / 50$ total result.

Once more, we stress that this is a clear way as to focalize management towards these two latest categories, in order to improve them. 


\section{Table 19. Summary of results, per mutualistic principle and per CSR category}

\begin{tabular}{|l|ccccc|}
\hline Principles & $\begin{array}{c}\text { Human } \\
\text { resources }\end{array}$ & $\begin{array}{c}\text { Products and } \\
\text { Services }\end{array}$ & Sustainability & $\begin{array}{c}\text { Community } \\
\text { relationship }\end{array}$ & Environment \\
\hline Solidarity & $\searrow$ & $\nearrow$ & $\leftrightarrow$ & $\nearrow$ & $\searrow$ \\
Equality & $\searrow$ & $\searrow$ & & $\searrow$ & \\
Social Cohesion & $\searrow$ & & $\searrow$ & $\nearrow$ & $\nearrow$ \\
Solidarity /Social Cohesion & & $\nearrow$ & & $\nearrow$ & $\searrow$ \\
Networking & $\searrow$ & $\nearrow$ & & & \\
\hline
\end{tabular}

SOURCE: prepared by the authors.

From the results above mentioned, we are lead to the conclusion that LASMVNG is achieving a positive level of disclosure in terms of the mutual principles of Solidarity, Social cohesion, and Networking, in a total of 18 indicators, always showing a particular relief on Products/Services and Community Relationship categories.

Regarding Equality and Social cohesion indicators (in a total of 8), the results are negative.

Last but not least, Solidarity indicators (17 in total) bring out again the Products/Services and Community Relationship aspects with further positive expression, contrary to the parameters obtained on the Human Resources, Sustainability and Environment aspects, all negatively evaluated.

\section{5.- Conclusions}

We emphasize the following conclusions:

1. Social economy, whose genetic code integrates CSR, is not separate from the evolution of the concept of CSR itself, which leads the social economy entities (SEE) to seek, strategically, a more inclusive and attentive management, both on their internal and external surroundings, focusing on a triple bottom-line concept: Economic, Social, and Environmental aspects have to be considered. Adequate strategies are imposed, as far as new realities demand a better vision and planning of their actions, new and appropriate implementation procedures, and accurate controlling methods. In a word, it appeals to the reinforcement of governance, ethics, and integrity. All of this is needed so that the social object 
pursued is achieved; they would have to generate value, translating their socially responsible behavior. Without those, they will not be granted their required legitimacy and credibility.

2. SEEs shall, therefore, provide proof, in a most transparent way, that they perform according to that responsible behavior, attending to the general interest they strive to promote through their actions.

3. Therefore, we shall say that disclosure of their performance is a must, not confined to financial terms (financial report), but also made in terms of sustainability (sustainable report or integrated reporting), which is of the highest importance to all stakeholders.

4. In this context, we propose the adoption, as mandatory, of a report that will entirely fulfill the disclosure needs detected, which in our opinion is the integrated reporting. Disclosure would turn up more dynamic, actual, and complete, then providing the transparency to the SEEs, as required by the interest groups.

5. Our case study enabled us to identify the great difficulty on disclosing, at least at the required level, despite the conclusion that the mutual association studied showed to have disclosure worries far beyond those legally required.

6. Concerning the major constraints of this study, we would like to point out the absence of sustainable reports by social economy entities that could already prepare sustainable reports (even less, integrated reporting). Moreover, we had serious difficulties with the access to the accounts reports in general, even if we have contacted directly a large number of mutual associations for this purpose, as specified in the case study.

7. It would have been very important to extend this case study to other mutual associations, in order to establish comparisons, possible outcomes and drawing of conclusions. This has not been feasible either by the lack of access to documents shown, or by the tight schedule imposed.

\section{Future investigations}

The continuous evolution of these issues will require further research and monitoring, where education for citizenship and ethics will certainly play a crucial role.

In addition to the limitations stressed, in our opinion, it will be most interesting and relevant to build up a benchmarking process between several SEE, enhancing the adoption of forms of disclosure more transparent and effective, and finally improving their sustainability. 


\section{Bibliography}

BAKKER, P. (2013): Integrated reporting will challenge the current thinking on value creation, available from: http://www.wbcsd.org. [Accessed: 23th October 2013].

CASES - Cooperativa António Sérgio para a Economia Social (2013): Contas Satélite da economia nacional, available from: http://www.cases.pt/atividades/contasatelitees. [Accessed 28th October 2013].

CASTELO-BRANCO, M. (2006): Essays on corporate social responsibility and disclosure, PhD Thesis, Portugal: University of Minho.

COMMISSION OF THE EUROPEAN COMMUNITIES (2001): Green book: Promoting a European framework for Corporate Social Responsibility, COM (2001) 366, available from: http://ec.europaeu. [Accessed: 28th October 2013].

EUROPEAN COMMISSION (2011): Promoting a European framework for Corporate Social Responsibility, available from: http://ec.europa-eu. [Accessed 28th October 2013].

EUROPEAN COMMISSION (2013): Promoting a European framework for Corporate Social Responsibility, available from: http://www.eur-lex.europa.eu. [Accessed 28th October 2013].

DIMAGGIO, P. \& POWELL, W. (1983): "The Iron Cage Revisited: Institutional Isomorphism and Collective Rationality in Organizational Fields", American Sociological Review, 48.

FREEMAN, R.E. (1984): Strategic management - a stakeholder approach, 1st. ed. Boston: Pitman.

FRIEDMAN, M. (1970): "The social responsibility of business in to increase its profits", NY times magazine, 32-33, 122-124. Available from: http://faculty.wwu.edu/dunnc3/present.friedman.pdf [Accessed 04th July 2014].

GRI - Global Report Initiative (2013): G4 Guidelines, available from: http://www.globalreporting.org. [Accessed 05th November 2013].

HEAL, G. (2005): "Corporate social responsibility: An economic and financial framework", The Geneva papers on risk and insurance, 30, 387-409. Available from: http://ssrn.com/abstract=642762 [Accessed 22th October 2014].

IIRC - International Integrated Reporting Council (2013a): Integrated reporting will challenge the current thinking on value creation, available from: http://www.theiirc.org. [Accessed 05thNovember 2013].

IIRC - International Integrated Reporting Council (2013b): The International IR framework, available from: http://www.theiirc.org/wp [Accessed 05th November 2013]. 
INE - Instituto Nacional de Estatística (2013): Contas satélite da Economia Social, available from: http://www.ine.pt/xportal//xmain?xpid=INE\&xpgid=ine_cnacionais. [Accessed 28th October 2013].

JAMALI, D. \& MIRSHAK, R. (2006): "Corporate social responsibility (CSR): Theory and practice in a developing country context", Journal of business ethics, 72, 243-262. Available from: http://eprints.soton.ac.uk/47703/ [Accessed 25th October 2014].

KIRAN, R. \& SHARMA, A. (2011): "Corporate social responsibility: A corporate strategy for new business opportunities", Journal of international business ethics, 4 (1), 10-17. Available from: http://www.americanscholarspress.com/content/BusEth_Abstract/v4n111art2.pdf [Accessed 15thOctober 2014].

MEIRA, D.A. (2011): "A responsabilidade social da empresa cooperativa. Uma análise jurídica e intercultural", in: Diálogos interculturais: os novos rumos da viagem, Vida Económica, 293-305.

MEIRA, D.A. (2012a): "Cooperative social responsibility: An Intercultural Analysis". In: In Permanent Transit. Discourses and Maps of the Intercultural Experience, Cambridge Scholars Publishing, 127-144.

MEIRA, D.A. (2012b): "Iniciativas pioneiras en torno a la responsabilidad social corporativa: la Bolsa de Valores Sociales en Portugal', In Angel Fernández (Dir.), Elena Fátima Pérez (Coord.): Empresa responsable y crecimiento sostenible: aspectos conceptuales societarios y financieros, Revista Derecho de Sociedades, Thomson Reuters Aranzadi, 291-308.

MEIRA, D.A. (2013): "A Lei de Bases da Economia Social Portuguesa: do projeto ao texto final". CIRIEC-España, revista jurídica de economía social y cooperativa, 24, 21-52.

MELO NETO, F.P. \& FROES, C. (1999): Responsabilidade social e cidadania empresarial: A administração do terceiro sector, 1st ed. Rio de Janeiro: Qualitymark.

MEYER, J. \& ROWAN, B. (1977): "Institutionalized Organizations: Formal Structure as Myth and Ceremony", The American Journal of Sociology, 83 (2), 340-363. Available from: https://www2.bc.edu/ jonescq/mb851/Mar26/MeyerRowan_AJS_1977.pdf [Accessed 13th November 2014].

MONEVA, J.M., ORTAS, E. \& ACERO, I. (2013): "Divulgación de la información de responsabilidad social en las cooperativas de crédito y cajás de ahorro aragonesas", CIRIEC-España, Revista de Economía Pública, Social y Cooperativa, 77, 5-29.

NICOLAU, I. \& SIMAENS, A. (2008): "O impacto da responsabilidade social das empresas na economia social", Revista Portuguesa e Brasileira de gestão, 7:1, 68-76.

OECD (2010): SMEs, entrepreneurship. Innovative SMEs and Entrepreneurship for Job Creation and Growth, available from: http://www.oecd.org/cfe/smes/46404350.pdf. [Accessed 2nd November 2013]. 
SOCIAS, A. \& HORRACH, P. (2013): "Enfoque de la responsabilidad social y la transparencia en empresas de economía solidaria", CIRIEC-España, Revista de Economía Pública, Social y Cooperativa, 77, 31-57.

TORRE, P.R. (2005): "Responsabilidad Social Corporativa". In: Responsabilidad social corporativa: aspectos jurídico-económicos, 1st ed. Castelló de la Plana: Publicacions de la Universitat Jaume I: Servei de Comunicació i Publicacions.

UMP - União das Mutualidades Portuguesas (2013): Registo das associações mutualistas, available from: http://mutualismo.azurewebsites.net/Preen/Pesquisar/Porto. [Accessed 25th October 2013].

VELASCO, G.E. (2005): "Interés social, buen gobierno y responsabilidad social corporativa". In: Responsabilidad social corporativa: aspectos jurídico-económicos, 1st ed. Castelló de la Plana: Publicacions de la Universitat Jaume I: Servei de Comunicació i Publicacions.

WBCSD - World Business Council for Sustainable Development (2013): Sustainable development, available from: http://www.wbcsd.org. [Accessed 04th November 2013].

\section{CONSULTED LEGISLATION}

Constituição da República Portuguesa (1976). Edições Almedina, SA (2009) = Portuguese Constitution.

DL nr. 36-A/2011 09thMarch, Diário da República, $n^{0} 48$ - $1^{\text {a }}$ série, Assembleia da República, Lisboa.

DL nr. 119/1983 25thFebruary, Diário da República $n^{\circ} 46-1^{2}$ série, Assembleia da República, Lisboa $=$ Portuguese PISS Statute (revoked Nov. 2014).

DL nr. 172-A/2014 14thNovember, Diário da República nº 221 - $1^{\text {a }}$ série, Assembleia da República, Lisboa $=$ Portuguese PISS Statute. 


\section{Annex 1. Mutual Associations registered on Social Security}

\begin{tabular}{|c|c|c|c|c|}
\hline District ${ }^{4}$ & City & Denomination & Phone & E-mail \\
\hline \multirow[t]{3}{*}{ Aveiro } & Espinho & A Familiar de Espinho Associação de Socorros Mútuos & 227341570 & geral@familiardeespinho.pt \\
\hline & Ovar & A Mutualidade de Santa Maria Associação Mutualista & 256759040 & mutualidade.s.m@mail.telepac.pt \\
\hline & Espinho & Associação de Socorros Mútuos de S. Francisco de Assis de Anta & 227340103 & gera@@associacaoanta.com \\
\hline \multirow[t]{3}{*}{ Braga } & Guimarães & Associação de Socorros Mútuos Artística Vimaranense & 253263454 & asmavg@gmail.com \\
\hline & Braga & Associação de Socorros Mútuos Fúnebre Familiar Bracarense & 253263454 & asmffb@gmail.com \\
\hline & Guimarães & Associação de Socorros Mútuos Familiar Vimaranense & 253412397 & geral@afvimaranense.pt \\
\hline \multirow[t]{2}{*}{ Bragança } & Bragança & Associação de Socorros Mútuos dos Artistas de Bragança & 273329629 & geral@asmab.org \\
\hline & Mirandela & Associação de Socorros Mútuos dos Artistas Mirandelenses & 278265749 & $\mathrm{n} / \mathrm{a}$ \\
\hline CasteloBrancc & co Covilhã & Associação de Socorros Mútuos Mutualista Covilhanense & 275310870 & asmcmutualista@gmail.com \\
\hline \multirow[t]{2}{*}{ Coimbra } & Coimbra & A Previdência Portuguesa Associação Mutualista & 239828055 & geral@aprevidenciaportuguesa.pt \\
\hline & Coimbra & Mutuália - Federação Mutualista & 239837031 & mutualia@sapo.pt \\
\hline \multirow[t]{2}{*}{ Évora } & Évora & Legado do Caixeiro Alentejano Associação Mutualista & 266760680 & legado@mail.telepac.pt \\
\hline & Évora & O Legado do Operário de Évora Associacão Mutualista & 266702353 & loeasmutualista@gmail.com \\
\hline \multirow[t]{5}{*}{ Faro } & Faro & Associação de Socorros Mútuos Protectora dos Artistas de Faro & 289824440 & associacaoartistas@sapo.pt \\
\hline & Tavira & Montepio Artístico Tavirense Associação de Socorros Mútuos & 281327125 & montepioartisticotav@sapo.pt \\
\hline & Silves & Associação de Socorros Mútuos João de Deus & 282440030 & geral@asmjoaodedeus.pt \\
\hline & Faro & Mutualidade Popular Associação Mutualista & 289822411 & mutualidade.popular@mail.telepac.pt \\
\hline & Lagos & A Lacobrigense Associação de Socorros Mútuos & 282764826 & geral@alacobrigense-asm.pt \\
\hline Guarda & Guarda & Associação de Socorros Mútuos Montepio Egitaniense & $n / a$ & $\mathrm{n} / \mathrm{a}$ \\
\hline Leiria & Caldas da Rainha & Associação de Socorros Mútuos Rainha D. Leonor & 262837100 & geral@montepio-rdl.pt \\
\hline \multirow[t]{19}{*}{ Lisboa } & Lisboa & Associação de Socorros Mútuos Montepio Filarmónico & 213422745 & montepiofilarmonico@gmail.com \\
\hline & Lisboa & Montepio Geral Associação Mutualista & 213249805 & sec.geral@montepio.pt \\
\hline & Vila Franca Xira & A. de Socorros Mútuos Fraternal dos Artistas Vila-franquenses & 263276801 & contabgab@gmail.com \\
\hline & Lisboa & A. de Socorros Mútuos dos Empregados no Comércio e Indústria & 218843120 & asmeci@asmeci.org \\
\hline & Lisboa & Associação de Socorros Mútuos dos Empregados do Estado & 213258997 & asmee@mail.telepac.pt \\
\hline & Lisboa Asso & sociação de Socorros Mútuos de Empregados no Comércio de Lisboa & 218813300 & administracao@clinicasaocristovao.pt \\
\hline & Lisboa & Caixa Auxiliar de Socorros dos Operários da Cordoaria Nacional & 2 de Maio de 1895 & $\mathrm{n} / \mathrm{a}$ \\
\hline & Lisboa & Montepio Comercial e Industrial Associação de Socorros Mútuos & 213470552 & mcimutua1899@gmail.com \\
\hline & Póvoa Sta. Iria & Associação de Socorros Mútuos Dora (loures) & n/a & $\mathrm{n} / \mathrm{a}$ \\
\hline & Lisboa & Associação de Socorros Mútuos Almirante Cândido dos Reis & n/a & $n / a$ \\
\hline & Lisboa & Casa da Imprensa Associação Mutualista & 213420277 & administracao@casadaimprensa.pt \\
\hline & Lisboa Cail & aixa Auxiliar dos Estivadores do Porto de Lisboa e Centro de Portugal & $\mathrm{n} / \mathrm{a}$ & $\mathrm{n} / \mathrm{a}$ \\
\hline & Lisboa & Associação de Socorros Mútuos Mutualidade Ocidental & $\mathrm{n} / \mathrm{a}$ & $\mathrm{n} / \mathrm{a}$ \\
\hline & Lisboa & Cofre de Previdência dos Arsenalistas da Marinha & $n / a$ & $n / a$ \\
\hline & Lisboa & Associação de Socorros Mútuos Aliança Mutualista & 213908505 & $n / a$ \\
\hline & Lisboa & Associação de Socorros Mútuos dos Ourives de Lisboa & n/a & $n / a$ \\
\hline & Lisboa & União das Mutualidades Portuguesas Praça Pasteur, $3-2^{0}$ Esq. & 218446170 & uniao@mutualismo.com \\
\hline & Lisboa & MONAF Montepio Nacional da Farmácia & 213400690 & monaf@anf.pt \\
\hline & Cascais & Associação Mutualista dos Profissionais de Banca dos Casinos & $n / a$ & $\mathrm{n} / \mathrm{a}$ \\
\hline
\end{tabular}

4.- 18 Districts + Azores e Madeira; Districts of Vila Real, Portalegre, Beja, Azores e Madeira without any registration.

CIRIEC-España, Revista de Economía Pública, Social y Cooperativa

ISSN: 0213-8093

№ 85/2015, pp. 109-142 


\begin{tabular}{|c|c|c|c|c|}
\hline & Lisboa & AMCTA Associação Mutualista dos Controladores de Tráfego Aéreo & n/a & n/a \\
\hline & Lisboa & Associação Mutualista Aduaneira & $n / a$ & $\mathrm{n} / \mathrm{a}$ \\
\hline & Cascais & Associação Mutualista dos Profisssionais de Jogo & n/a & $\mathrm{n} / \mathrm{a}$ \\
\hline & Lisboa & MUDIP Associação Mutualista Diplomática Portuguesa & 213943284 & mudip@mne.pt \\
\hline & Lisboa & AMUSA Associação Mutualista dos Trabalhadores da Saúde & $n / a$ & $n / a$ \\
\hline & Lisboa & Associação Mutualista dos Trabalhadores da Solidariedade e Seg.Social & $n / a$ & n/a \\
\hline & Lisboa & AME - Associação Mutualista dos Engenheiros & 213535366 & secretaria@mutualidadedeengenheiros.pt \\
\hline \multirow[t]{36}{*}{ Porto } & Porto & Associação Portuense de Socorros Mútuos das Classes Laboriosas & n/a & $\mathrm{n} / \mathrm{a}$ \\
\hline & Porto & Associação Comercial de Socorros Mútuos no Porto & $n / a$ & $\mathrm{n} / \mathrm{a}$ \\
\hline & Porto & A Previdência Familiar do Porto Associação de Socorros Mútuos & 225371108 & gera|@previdencia.pt \\
\hline & Porto & A Beneficência Familiar Associação de Socorros Mútuos & 222087520 & geral@abeneficencia.org \\
\hline & Vila Nova Gaia & Associação Vilanovense de Socorro Mútuo & 223754711 & gera@@avilanovense.pt \\
\hline & Matosinhos & Associação de Socorros Mútuos de S. Mamede de Infesta & 229010549 & geral@asmmamede.com \\
\hline & Paços Ferreira & Associação de Socorros Mútuos Freamundense & 255879831 & cij.andorinha@mail.telepac.pt \\
\hline & Porto & Glória Portuguesa Associação de Socorros Mútuos & 222000603 & geral@gloria-am.pt \\
\hline & Porto & Mealheiro Postal Associação Mutualista & 222001749 & mealheiropostal@gmail.com \\
\hline & Grijó & Associação de Socorros Mútuos Fúnebre Familiar Circunvizinhas & 227640162 & asmgrijo@sapo.pt \\
\hline & Avintes & Associação de Socorros Mútuos Restauradora de Avintes & 227820240 & asm.restauradora@ live.com.pt \\
\hline & Vila Nova Gaia & Associação Fúnebre de Socorros Mútuos de Santa Marinha & 223752014 & $\mathrm{n} / \mathrm{a}$ \\
\hline & Oliveira do Douro & Associação Oliveirense de Socorros Mútuos e Fúnebre & 227820099 & aoliveirense@sapo.pt \\
\hline & Gondomar & A. de Socorros Mútuos de S. Bento das Peras de Rio Tinto & 224890107 & geral@associacaosaobento.com \\
\hline & Maia & A. de Socorros Mútuos Fúnebre Familiar em Moreira da Maia & 229449270 & mail@am-moreira.pt \\
\hline & Valadares & Associação Mutualista de Arcozelo & 227537000 & mutualista.arcozelo@gmail.com \\
\hline & Valongo & Associação de Socorros Mútuos e Fúnebre do Concelho de Valongo & 224220135 & asmfcv@gmail.com \\
\hline & Carvalhos & Associação de Socorros Mútuos Fúnebre Familiar de Pedroso & 227837276 & asmp-geral@sapo.pt \\
\hline & Vila do Conde & Associação Socorros Mútuos em Modivas & 229270048 & asmmodivas@sapo.pt \\
\hline & Valadares & A. de Socorros Mútuos Fúnebre Nosso Senhor dos Aflitios & 227110240 & ass.n.s.afl.valadares@hotmail.com \\
\hline & Carvalhos & A. de Socorros Mútuos Nossa Senhora da Esperança & 227633001 & associacao.sandim@associacaosandim.com \\
\hline & Porto & Liga das Associações de Socorro Mútuo do Porto & 223395493 & liga.porto@clix.pt \\
\hline & Porto & A Vencedora - Associação de Socorros Mútuos & 225379562 & geral@vencedora.pt \\
\hline & Valadares & Associação de Socorros Mútuos de Serzedo & 227620268 & geral@asms.pt \\
\hline & Vila Nova Gaia & Liga das Associações de Socorros Mútuos de Vila Nova de Gaia & 223771015 & geral@ ligagaia.pt \\
\hline & Penafiel & Associação Fúnebre Familiar Penafidelense de Socorros Mútuos// & & \\
\hline & & Associação de Socorros Mútuos Artística Penafidelense & n/a & $\mathrm{n} / \mathrm{a}$ \\
\hline & Carvalhos & A. de Socorros Mútuos Fúnebre Nossa Senhora da Conceição & 227650679 & antoniomoreiradesa@gmail.com \\
\hline & Póvoa do Varzim & Associação de Socorros Mútuos da Póvoa de Varzim & 252624536 & familiar.asm@gmail.com \\
\hline & Porto & A Restauradora em Ramalde Associação de Socorros Mútuos & n/a & $n / a$ \\
\hline & Porto & A Lutuosa de Portugal Associação Mutualista & 222005135 & geral@alp-mutualismo.pt \\
\hline & Porto & Previdência dos Ferroviários de Portugal A. de Socorros Mútuos & 223321068 & alvirapinheiro@sapo.pt \\
\hline & Porto & Associação de Socorros Mútuos A Prevenção do Porto & n/a & $n / a$ \\
\hline & Porto & A Benéfica e Previdente Associação Mutualista & 222046380 & benefica-previdente@benefica-previdente.com \\
\hline & Porto & Associação Mutualista de Auto Sueco, Lda. & 226150300 & melvira@autosueco.pt \\
\hline & Porto & Casa do Artista A.M.A.R. Associação Mutualista dos Artistas & 222011326 & casadoartistanorte@amar.com.pt \\
\hline
\end{tabular}




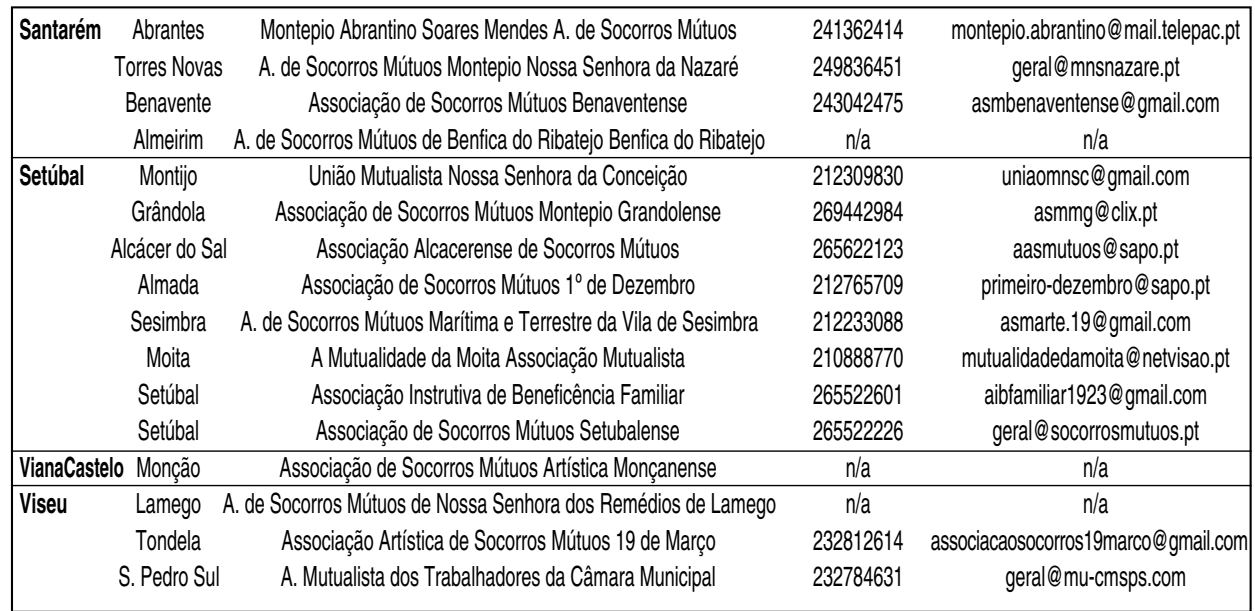

SOURCE: prepared by the authors, adapted from UMP e DIRECÇÃO-GERAL DA SEGURANÇA SOCIAL (Model DGSS/08) - Mutuals Registration. 